\title{
The Diaspora Project on Education Sector: Cultivating Positive Perception of Indonesia Through International Education
}

\author{
Ratih Indraswari* \\ Department of International Relations, Parahyangan Catholic University, \\ Bandung-Indonesia \\ Nyoman Mas Aryani ${ }^{* *}$ \\ Department of Constitutional Law, Faculty of Law Udayana University, \\ Bali-Indonesia
}

Article Received: 28 th December 2018 Accepted: 4th July 2019; Published: $31^{\text {st }}$ July 2019

\begin{abstract}
The massive support to develop a new category of Indonesian Diaspora that is called as a "special friends of Indonesia' (Indonesianist) seems would remain become a domain of academic and public debates. The existing Indonesian law and regulations, even though have been amended many times and during the debates on law creating process have tried to adopt the model of dual citizenship, do not affirm this new category. Despite this current legal situation, this article argues that this special friend can be cultivated from the international education section. This paper is academic research in the field of social sciences, especially international relations that analyzes statements, views, and opinion by government officers, diaspora, and Indonesianists as well as some law and regulations. The research suggests that the concept of Special Friends of Indonesia (Indonesianists) is too broad and poses a challenge for the conceptual and legal definition. Fully considering the high contribution of Indonesianist, nurturing of future Indonesianist - especially through student mobility programs - is best to take place in the situation allowing for exposure and socialization process to be built internally.
\end{abstract}

Keywords: Indonesia; Diaspora; Category; International Education

How to cite (Chicago 16th): Indraswari, Ratih, and Nyoman Mas Aryani. "The Diaspora Project on Education Sector: Cultivating Positive Perception of Indonesia Through International Education." Udayana Journal of Law and Culture 3, no. 2 (2019): 123-140. https://doi.org/10.24843/UJLC.2019.v03.i02.p01.

doi: https://doi.org/10.24843/UJLC.2019.v03.i02.p01

\footnotetext{
*Email/Corresponding Author: ratih.indraswari@unpar.ac.id

** Email: mas_aryani@unud.ac.id
} 


\section{Introduction}

\subsection{Background}

The term diaspora has received scholars' attention during the last two decades. Its utilization is shared by different fields of study with wide dispersion based on traditional geographical consideration, expanded into that of language, religious, politic, economic and other transnational issues. Diaspora is inherently linked to the idea of homeland. Although, debates on whether 'home' is limited into a set of geographical boundaries instead of an imagined community that is constructed through value are prevalent. Yet diaspora still is not independent of the link to that origin state.

Globalization further supports the establishment of periphery community away from the core community. This geographical context shares a certain linkage beyond the understanding of formal citizenship. It touches upon the constructed meaning of blood running through their descendant in the form of identity. As a consequence, states across the globe have acknowledged the existence of a community of their own beyond national borders. Policies on engagement have been enacted into several degrees of an integrative approach, ranging from acceptance for dual citizenship into quasicitizenship status.

Indonesia does not accept dual citizenship status. The experience of political turmoil during the colonialization era contributes to Indonesian fears of foreign intervention through the 'ambiguity' of loyalty carried by the dual citizenship status. However, the Indonesian government has made an effort to integrate diasporic communities abroad by the introduction of regulation of Oversea Indonesia Community in 2017. Discourse on Indonesia diaspora reached its peak on the establishment of Indonesia Diaspora Network in 2012. This network proposes four (4) categories of diaspora involving citizen Indonesia abroad, Indonesian who have relinquished their citizenship, foreign descendants of Indonesian and Indonesianist (special friends of Indonesia). The first three categories are covered by Indonesian regulation on the diasporic community. However, the fourth one has been a matter of scholarly debate as the lack, if not in existence, of the conceptual background to support it.

The unviable support of conceptual and legal aspect to the last category certainly poses challenges in understanding it, yet it does not mean that it is not contributive to Indonesia's interests. On the $30^{\text {th }}$ of November 2018 in Bali, the Ministry of Foreign Affairs of Indonesia launched its first Indonesianist Forum. This forum invites Indonesianist speakers and extends its engagement by cooperating with universities across Indonesia to send their foreign students to participate in the forum. It is argued that the forum is a venue for 'friends' of Indonesia to share and nurture the interest and attractiveness toward Indonesia development. Borrowing the conceptual approach of soft power, nurturance of Indonesia's special friends displays 
the attractiveness of Indonesia within the international stage. Defining who Indonesia's special friend is, is the next challenge to be addressed.

\subsection{Purpose}

This paper argues that this special friend can be cultivated from the international education section. Two important understanding came out of this argument.

1. Special friend refers to foreign students who have been spending their time in Indonesia. They have experienced Indonesia through their live-in experience and have been exposed to and even internalized the values and norms of Indonesia's society. They might be, as of now, do not exhibit the high quality required to be 'special friend of Indonesia'. But certainly, they have the potential to be one in the long future. This will highly dependent on their experiences on prearrival, during their time in Indonesia and post their time.

2. International education is the breeding ground of mutual exchanges of different backgrounds emphasizing by people to people connection. Higher Education Institution (HEI) plays an important role in this section. Internationalization strategies in favour of the increased of global students flow to allow for the interaction to take places. Thus successful internationalization strategies of HEI in encouraging for student mobility needs support from the government. Fortunately, globally the finding shows that students' mobility is the policy area receiving the most support from policymakers. ${ }^{1}$

\subsection{Method}

This article reflects academic research in the field of social sciences, especially international relations. It applies concept and theories that may be applied to explain the issues discussed, for example, nationality, national interest, soft power, diplomacy, and State authority. Comparative studies were conducted to present situation in ASEAN countries such as Malaysia, Singapore, Thailand, and Vietnam. Statements, views, and opinion by government officers, diaspora, and Indonesianists are used to clarify relevant facts. In order to give a legal background and to provide legal definition to some concepts, this article cites some international legal instruments and Indonesian laws and regulation.

1 Janet Ilieva and Michael Peak, "The Shape of Global Higher Education: National Policies Framework for International Engagement," British Council, 2016; Janet Ilieva, Pat Killingley, Vangelis Tsiligiris, and Michael. Peak. "The Shape Of Global Higher Education: International Mobility of Students, Research and Education Provision". Volume 2. London: British Council, 2017. 
The Diaspora Project on Education Sector:

Cultivating Positive Perception of Indonesia

Through International Education

Ratih Indraswari and Nyoman Mas Aryani

\subsection{Literature Review}

The definition of diaspora hardly reached a consensus amongst academicians. Its original idea however highly related to that of mobility out of a home that is rigidly linked to a certain area of geography. Attempts to break out the demarcated area cause individual to gain a different categorization.

Works on the classical discussion of diaspora show it is identic with the concept of homeland. ${ }^{2}$ Early writings on Diaspora were focusing on that of displacement from the homeland, depicting marginalization experienced through victim diaspora in cases such as the Jewish, Greek, and Armenian diaspora. ${ }^{3}$ Scholars of diaspora generally agree that diaspora is identic with migration, homeland orientation and the existence of the border. ${ }^{4}$ Thus, the traditional perspective often uses the references of displacement and marginalization as the highlight of diaspora discourse. ${ }^{5}$

Even though diaspora is easily connected with ethnicity, mobility, and displacement, a more positive light emerge by arguing that diaspora should better be seen in light of connectivity. ${ }^{6}$ Diaspora concept is also not statically defined as given communities generated by shared ethnicity and national group solely, but it is also an imagined community that continuously reconstructed and reinvented. ${ }^{7}$ Conceptually, diaspora should be expanded to understand that its transnationalism is not always negative but can create a positive aspect on diasporic communities. ${ }^{8}$

To argue about modern diaspora means to question the traditional idea of home. Home can be perceived as the place of return but it can be also perceived as a lived experience of the locality. Meaning home is not a specific place but it also constructed. ${ }^{9}$ Modern diaspora encourages the establishment of transnational connectivity that grows beyond the negative nuances. Instead, this transnational flows and linkage turn into the forces that intensify globalization. ${ }^{10}$ Diaspora thus, in essence, is a spatial issue.

\footnotetext{
(2005): $1-19$

${ }^{2}$ Roger Brubaker, “The 'Diaspora' Diaspora." Ethnic and Racial Studies 28, no.1

3 Robert Cohen, Global Diaspora: An Introduction. London: UCL Press, 1997

${ }^{4}$ Roger Brubaker, loc.cit.; Melvin Ember, Carol R Ember, and Ian Skoggard (Eds.). (2004). Encyclopedia of Diasporas: Immigrant and Refugee Cultures around the World. Volume I: Overviews and Topics; Volume II: Diaspora Communities. Springer Science \& Business Media.

5 William Safran, "Diasporas in Modern Societies: Myths of Homeland and Return." Diaspora: A Journal of Transnational Studies 1, no. 1 (1991): 83-99 "

${ }^{6}$ Roza Tsagarousianou, "Rethinking the Concept of Diaspora: Mobility, Connectivity and Communication in a Globalised World." Westminster Papers in Communication and Culture 1, no. 1 (2004): 52-65

7 Ibid.

8 Robert Cohen, loc.cit.

${ }^{9}$ Avtar Brah, Cartographies of Diaspora: Contesting identities. New York: Routledge, 2005.

10 James Clifford, Routes: Travel and Translation in The Late Twentieth Century.
} Cambridge MA: Harvard University Press, 1997 
The contribution of the modern world will bore a different significant due to technological advancement. Geographical proximity no longer has a hindering standing, as linkages are sustained by globalization.

Diaspora has transformed from a technical term of philosophy into a term used by different fields and subfields study across humanities and social sciences. Unavoidably, the diaspora has been widely used in media and popular culture. Scholars identify diaspora due to its continued involvement with homeland politics, ${ }^{11}$ or the increasing economic aim by labour migrants. ${ }^{12}$ Other argue that diaspora can be categorized through language as the unifying character of diaspora. Religions are not free from diasporic influences in the creation of trans-border religious communities. Certainly, the wide dispersion of diaspora will pose challenges on attempts to conceptualizing it. ${ }^{13}$ The increasing mobility steered by education seekers adds into the global equation of mobility above.

How the latter form of diaspora benefits Indonesia needed to be answered. Advocates of soft power argue that interest and attractiveness play a significant factor in co-opting people to support Indonesia. ${ }^{14}$ The cultivation of state's attractiveness can be attained through public diplomacy strategy. ${ }^{15}$ One of the public diplomacy models is the existence of exchange under international education. ${ }^{16}$ International education requires multi governance level in its approaches involving not only the state but also involves non-state actors. These non-state actors vary from higher education institutions, educational agencies, and international students. ${ }^{17}$

11 Gabriel (Gabi) Sheffer, "Transnationalism and Ethnonational Diasporism." Diaspora: A Journal of Transnational Studies 15, no. 1 (2006): 121-145.

12 Gabriel Sheffer. "Diaspora Politics: At Home Abroad". Cambridge: Cambridge University Press, 2003.

13 Brubaker, loc.cit.

14 Joseph S. Nye, "Public Diplomacy and Soft Power." The Annals of the American Academy of Political and Social Science 616, no. 1 (2008): 94-109.

15 Jan Melissen, The New Public Diplomacy: Soft Power in International Relations New York: Palgrave Macmillan, 2005; Jan Melissen, "Public Diplomacy," in The Oxford Handbook of Modern Diplomacy ed. Andrew F. Cooper et al. Oxford: Oxford University Press, 2013. Press, 2009.

16 Nicholas J. Cull, Public Diplomacy: Lessons from the Past. Los Angeles: Figueora

17 Bob Sugeng Hadiwinata, "Reciprocity and Relationship Building through Education: the ACICIS Field Study Program in West Java," in Linking People: Connections and Encounters between Australians and Indonesians Berlin: Regiospectra, 2015: 135-152; Jemma Purdey, "Investing in good will: Australia's Scholarship Programs Ffr Indonesian Tertiary Students, 1950s-2010," in Linking people: Connections and encounters between Australians and Indonesians (Berlin: Regiospectra, 2015): 111-132; Caitlin Byrne and Rebecca Hall, "Australia's International Education as Public Diplomacy: Soft Power Potential," Clingandael Discussion Papers in Diplomacy Vol.121 (2011); Caitlin Byrne and Rebecca Hall, "Realizing Australia's International Education as Public Diplomacy," The Australian Journal of International Affairs 647, no.4 (2013): 419-438; Caitlin Byrne and Rebecca Hall., "International Education as Public Diplomacy," Research Digest 3 (2014). 
The Diaspora Project on Education Sector:

International education provides the venue for interaction to take place between foreigner and Indonesian through its exchange platform. Mutual understanding can be realized on the foundation of people to people contact as attractiveness is highly related to emotional construction. Exchange in this context highlights the experiences of foreign students in Indonesia making them a great potential agent to support Indonesia's development.

\section{Result and Analysis}

\subsection{Defining the Concept of 'Special Friend of Indonesia' as a New Meaning of Diaspora}

\subsubsection{Indonesia Government Stance on Diaspora}

Referring to Diaspora, Indonesia stance is certain on their disagreement to favour for dual citizenship. However, this does not mean that no effort has been taken to acknowledge diaspora by granting special status for their quasi-citizenship abroad referred to 'ethinizenship'. 18

Based on the data given by the Ministry of Foreign Affairs, it is counted that up to 4.3 million Indonesia's citizen living abroad, although further data on the classification has not been out yet. ${ }^{19}$

Indonesia's diaspora trend has shown that supporting factors for Indonesian to go abroad are triggered by sometimes mixed political, economic, and education factors. Political constraints of certain racial background in Indonesia have been prompting the migration out of Indonesia reaching its recent peak on the set of 1998 tragedies. Economically, Indonesia's outbound migration is mainly associated with migrant workers. With most Indonesian migrant workers taking low skilled employment abroad, they disagree on diaspora terminology itself. They argue the terminology is biased and subjected to inequality by exclusively referring to those of that elite position on white-collar instead of the bluecollar. The term of Indonesia's Diaspora has been received with a mixed feeling by Indonesian's citizen abroad. On the other side increasing economic growth and awareness of the quality of foreign education triggered the rise of education seeker. Hence, it is projected that Indonesia will overcome American in the number of student mobility by 2024 .

The issues concerning Indonesia diaspora rests heavily on fundamental issues of who is eligible to be called as diaspora? The

18 Rainer Baubock, "Stakeholder Citizenship and Transnational Political Participation: A Normative Evaluation of External Voting," Fordham Law Review Vol. 75 no.4 (2007); Harijanti et al., "Citizenship and the Indonesian Diaspora: Lessons from South Korean and Indian Experiences," Border Crossing 2 no.8 (2018): 297-310.

19 A. Basnur, "Pemberdayaan Masyarakat Indonesia di Luar Negeri Untuk Kepentingan Nasional," Kementerian Luar Negeri Republik Indonesia, 2017,

https://www.kemlu.go.id/id/lembar-informasi/Documents/ Paparan\%20 Direktur \%20Diplik\%20-\%20Forum\%20Bakohumas\%20Tematik\%20Kemlu\%202017.pdf. 
introduction of a new concept by the Indonesian Diaspora Network (IDN), ${ }^{20}$ create a positive conundrum forcing us to re-define the understanding of diaspora. Although citizenship and quasi-citizenship concept alike were addressed, problems in its implementation can still be found.

The international community pays a serious concern on the citizenship clarity of every person. It can be seen in Article 15 of the Universal Declaration of Human Rights (UDHR) that determines the right of everyone to have a nationality and the protection given to all persons not to be arbitrarily deprived of his/her nationality, nor denied the right to change his/her nationality. The International Covenant on Civil and Political Rights (ICCPR) that has been ratified by Indonesia through Law No. 12 Year 2005, puts a concern on the issue of citizenship and the right of the child. Article 24 (3) of this covenant explicitly says "Every child has the right to acquire a nationality."

Issue related to regulating of unlimited dual citizenship could be a concern by Indonesia's government. President Joko Widodo had signed two regulation for giving facility and ability for the diaspora to actively participate on the economic, social and culture development. The first regulation is Government Regulation No. 26 Year 2016 regarding Amendment of Government Regulation No. 31 Year 2013 regarding Implementation Regulation of Act No. 6 Year 2011 regarding Migration, on 27 June 2016. In Article 111 Paragraph (2) regulating visiting visa for several times of visiting for five years calculated since issued date, and Article 136 that amendment with three paragraph are paragraph (4), (5) and (6) regulating Residing Permit with exceptional for foreigner as ex Indonesia's Citizen and their family. They classify that the narrow definition can be covering three categories of diaspora namely the former Indonesian citizen, their spouse, and their children. The second regulation is Presidential Regulation No.76 Year 2017 regarding Facility for Overseas Indonesian Community, dated on 3 August 2017. The broader definition is found in Article 1 (3) clarifies foreigners as people who are not Indonesian citizens including former Indonesian citizens, children of former Indonesian citizens, and foreign citizens whose biological parents are Indonesian citizens who live and / or work abroad. Article 1(4) of this presidential regulation defines 'masyarakat Indonesia di Luar Negeri' (Overseas Indonesian Community) in are Indonesian citizens and foreigners who live and/or work abroad.

The Presidential Regulation No. 76 Year 2017 was aimed to engage the quasi-citizenship issues that alternate the 'no dual citizenship policy' as previously stipulated under Law No. 62 Year 1958 and Law No. 12 Year

20 Indonesian Diaspora Network. Deklarasi Diaspora Indonesia. http://www.diasporaindonesia.org/index.php/idn/programmes 
The Diaspora Project on Education Sector:

2006, both concerning the Citizenship of the Republic of Indonesia. The latest law gives an exemption to children before the age of 18. This presidential regulation also enables the government to issue Indonesian Community Card Abroad (KMILN) that is technically further regulated under Minister of Foreign Affairs of the Republic of Indonesia Regulation No. 7 of 2017 concerning the Issuance and Revocation of Indonesian Community Overseas Cards. Article 3 of this ministerial regulation determines that KMILN has the function of identification of Indonesian Society Abroad and potential mapping and networking tools for the Indonesian community abroad for national interests. The KMILN would not apply permanently as it is valid for 2 (two) years and can be extended (Article 6 and 7). The KMILN policy caused criticism from the diaspora because it considers the granting of the KMILN to be more about collecting data on the number of Indonesian citizens abroad and due to its non-automatically enabler of the existing facilities, applies to those who have relinquished their Indonesian citizen. The new regulation mostly gives benefits to an overseas Indonesian citizen, who are mostly migrant workers. ${ }^{21}$ But there are also positive opinions which argue that this is the first step for the Indonesian government's recognition of the existence of diaspora and the re-establishment of broken relations due to differences in passports. ${ }^{22}$

Courts in Indonesia do not play a role in clarifying or make progress to enlarge the meaning of diaspora. As far as concerns, there are no court decisions specifically dealing with the issue of diaspora. The most related case usually questions the issue of the requirements and procedures of becoming an Indonesian citizen. ${ }^{23} \mathrm{~A}$ potential diaspora jurisprudence due to the willingness of Indonesian Chinese expatriates holding foreign citizenship to obtain Indonesian citizenship that results in dual citizenship, would not be realized as these individuals have no legal standing before the Constitutional Court to submit a constitutional review on Law No. 12 Year 2006 concerning the Citizenship of the Republic of Indonesia. ${ }^{24}$

Facing the hopes of the diaspora to be given dual citizenship, it can be compared with the countries of India and South Korea that accommodates diaspora interests by providing immigration facilities. They have adopted quasi-citizenship for their descendants overseas. India created the Person of Indian Origin (PIO) card scheme in 1998 and the Overseas Citizens of India

21 Susi Dwi Harijanti, Bilal Dewansyah, Ali Abdurahman, and Wicaksana Dramanda. "Citizenship and the Indonesian Diaspora: Lessons from the South Korean and Indian Experiences."Border Crossing 8, no. 2 (2018). 297-310.

22 "Kehadiran Kartu Diaspora Indonesia Mendapat Tanggapan Negatif," DetikNews, https://news.detik.com/abc-australia/d-3613331/kehadiran-kartu-diaspora-indonesiamendapat-tanggapan-negatif

${ }^{23}$ See for example, Decision of the Constitutional Court of the Republic of Indonesia No. 80/PUU-XIV/2016, para [2.1]

24 Tundjung Herning Sitabuana, "Indonesian Chinese Diaspora, Dual Citizenship and Indonesian Development." Constitutional Review 1, no. 1 (2015): 50-71. 
(OCI) card scheme in 2003. The two schemes merged in 2015 into the Overseas Citizens of India Card Holder (OCC) that gives benefits not only in the form of visa exemptions for visiting and staying in India but also guaranteeing some legal rights with the exception of political participation. ${ }^{25}$ This means an exception in term of guaranteeing voting rights or to participate in elections and rights to hold public office. ${ }^{26}$ Different attitude is shown by the Korean Government, though the Immigration law regulated in the Act on the Immigration and Legal Status of Overseas Korean Act) in 1999 with the F-4 visa scheme with its amendment in 2004. This law gives benefits such as freedom of employment and economic activity, and national treatment with regard to real property rights and transaction, foreign exchange transactions and health insurance and pensions. ${ }^{27}$

India and South Korea have made a clear definition of their Diaspora as groups of former citizens and their descendants to a number of generations who live outside their native country. Based on that experience, Dewansyah has an opinion that Indonesia needs to rethink the diaspora category, mainly based on Dino Pati Djalal's opinion because it covers not only Indonesian citizens and their descendants but also Indonesian citizens abroad and foreigners who "love" Indonesia (Indonesianist/ special friends of Indonesia). ${ }^{28}$ That last category will lead to confusion because it will be difficult to make criteria and clear definition.

Reviewing from the description above, it can be concluded that everyone has the right to citizenship and Indonesian government sees that it is time for dual citizenship or quasi -citizenship to become a necessity for the diaspora. Nevertheless, it is deemed necessary to have a more in-depth study and discussion if there is a possibility of a way to revise the Citizenship Law adopted.

\subsubsection{Social Awareness}

Awareness of the potential contribution of Indonesian diaspora came late to Indonesia. Only in 2012, the first attempt of cultivation was introduced by establishing Indonesian Diaspora Congress, an initiative of Dino Patti Djalal, the Indonesian Ambassador to the United States of America in Los Angeles. This congress presuming the initiation of Indonesian Diaspora Network (IDN) which is followed by the second Congress in Jakarta in 2013 and the third Congress again in Jakarta in the year of 2015.

25 Susi Dwi Harijanti, et.al., op.cit., 298.

26 Sohali Verma, Instruments of engagement: Assessing India's PIO and OCI scheme, CARIM-India RR 2013/21, Robert Schuman Centre for Advanced Studies, San Domenico di Fiesole (FI): European University Institute, 2013.

27 Susi Dwi Harijanti, et.al, loc cit.

28 Ibid., 307. 
The Diaspora Project on Education Sector:

The fourth congress of the diaspora in 2017 shows an interesting milieu for the development of a new category on who can be considered as Diaspora. President Barack Obama was invited to address the Indonesian Diaspora Congress as a "special friends of Indonesia' due to its childhood history in Indonesia. This congress proposes a new trajectory for the focus of Indonesian Diaspora by introducing a concept of a special friend of Indonesia, which later on refer to Indonesianist. The idea of 'special friends of Indonesia' gives an anomaly to the existing concept and understanding of Diaspora, especially a problem on its legal definition.

IDN proposes the 4 categories of diaspora Indonesia; (1) Citizen Indonesia abroad, (2) Indonesian who have relinquished their citizenship, (3) Foreign descendants of Indonesian and (4) Indonesianist (special friends of Indonesia). The first three categories are well documented legally within the law and regulations as discussed in 2.1.1.

Scholars argue that the newly proposed categorization is too broad and pose a challenge for the conceptual and legal definition. It is difficult to develop an understanding as this categorization covering not only Indonesian citizen abroad and its descendant but also foreigners who their linked to Indonesia is not by blood or ancestry, but rest heavily on their 'love' for Indonesia. ${ }^{29}$ Despite the conceptual conundrum of establishing a conceptual framework for Indonesianist, we can not undermine nevertheless in its implication the contribution that can be captivated by Indonesia is paramount.

\subsection{Indonesian Diaspora and International education}

\subsubsection{Nurturing Indonesianist through International Education}

Indonesianist in basic is defined as foreign citizens who "love" Indonesia. It covers people from all sort of backgrounds of study and work. So diverse in its origin yet bounded by one thing, their likeness to Indonesia. This attractiveness, as conveyed by Nye as a soft power source, has the power to contribute to the betterment of Indonesia.

Contribution from Indonesianist can take a different form and deliver varying impact's intensity based on the individual capacity. However, we all can agree that prior to value internationalization that drives them to support Indonesia started, a certain degree of exposure toward Indonesian value, norms and culture must have been fulfilled.

Several 'big names' heralded as the Indonesianist such has developed an affinity toward Indonesia through external familiarity emerged due to socialization on political interaction. One hand, Dino Patti Djalal mentioned he is one of Indonesia's special friends based on his steady involvement in

${ }^{29}$ M. Iman Santoso, Diaspora, Globalisme, Keamanan dan Keimigrasian [Diaspora, Globalism, Security and Immigration]. Bandung: Pustaka Reka Cipta, 2014 
promoting and preferring Indonesia's. On the other hand, Barack Obama has the direct experiences living in Indonesia during his youth time, garnering a more internal familiarization on Indonesian's attractiveness. Hence, the socialization process necessitates the exchange of mutual understanding.

This paper argues that the nurturing of future Indonesianist is best to take place in the situation allowing for exposure and socialization process to be built internally. Especially highlighting the student mobility platform that allows students to move outside their origin environment, in which they are exposed to a novel value set. This, however, does not overlook that nurturance could also be flourished externally providing a stimulus environment is available.

In this sense using education playground as an incubator for the socialization process is highly appropriate for several reasons. First, education provides a neutral background as honest observation is collected. In contrast to a political or economic setting which internationalization process is influenced by corresponding interests. Second, mobility student commonly comprised as young adults and they create their understanding of the world through experimental learning. This formative stage is important for socialization values to construct a more understanding of multiculturalism. Third, student mobility provides a lengthy duration for students to immerse in the new environment. There is yet a definitive answer to support whether the duration students spent on is correlated positively with the degree of internationalization they have achieved. As cases show that even the short term program generated a better internationalization degree due to the level of exposure they have received, including high local friendship establishment and deep integration to the local social construction. To conclude it is certain to say that student mobility platform provides fertile ground to nurture the future Indonesianist.

\subsubsection{Indonesia Education Profile: Our Competitiveness in ASEAN Context}

Establishing a fertile ground for student mobility indicates suitable structure must be presented. Often we focus on the structure taking place in individual Higher Education Institution (HEI), as students' preferences rest significantly on the readiness of Host University. Nevertheless, the absence of enabling national structure and policy will hinder HEI to deliver appropriate readiness for student mobility to take place.

Student mobility, thus, is no longer an issue of sole internal reconfiguration, but expanded well into the realm of national and regional competition. Nationally, the recent decision of Directorate General of Higher Education, Indonesian Ministry of Research and Higher Education (hereinafter, DIKTI) to introduce a new indicator of foreign student number 
The Diaspora Project on Education Sector:

into their national ranking has re-emphasized its importance. At the same time, it signifies the need for structure improvement within individual HEI.

Although Indonesia does not yet adopt a concept of massive commercialization education nationally, we have to increase our education competitiveness. This speaks true when we look no further but into the ASEAN region. Indonesia's position within ASEAN on its education's provision is promising. Based on the research done by the British Council on The Shape of Global Higher Education: Understanding the ASEAN Region several key findings are achieved. The research aims to look at the member's national policies of international higher education. It tries to understand the policy environment and support national gives to HEI when relating to the internationalization activities, most notably student mobility. Regionally student mobility structure and policy are well established, with nine of ten countries score high or very high in this category. It implies that infrastructure to cater to these mobility presents within universities in ASEAN countries.

The scoring of the National Policies Frameworks looks at 3 main components; Open-ness identifies the government's commitment to internationalization by providing an environment to enable internationalization activities. Quality Assurance and Recognition identifies the regulatory environment to facilitate internationalization activities. Last, Access and Sustainability identifies the promotion of internationalization activities.

On the first indicator, Indonesia ranks the $5^{\text {th }}$ after Malaysia and Thailand, both occupying very high, and followed by Vietnam, Singapore, and Indonesia, in which all these countries fare high on their score of openness. This indicates that internationalization strategy is present; on students and academic mobility including visa procedures and integration of international research to national assessment as well as institutional and program mobility on cross border provision. However, challenges pointed out that even Visa Students is present, its process is still a complicated matter and time-consuming. Cross-section management between Directorate General of Immigration-Ministry of Law and Human Rights and DIKTIMinistry for Research and Higher Education requires more coordinating attempts. Efforts have been done, with the introduction of online application and electronic signature to ease the process. ${ }^{30}$ Despite the administrative hindrances, Director General of Institutional of the Indonesian Ministry for Research and Higher Education Patdono Suwignjo stated that during the year of 2016, 6.967 study permit has been done by -

30 Neneng Zubaidah, “Jumlah Mahasiswa Asing Meningkat," Koran Sindo, http://koran-sindo.com/page/news/2017-05- 
DIKTI. But the number is relatively low in comparison to Malaysia which aims to reach 250.000 in $2025 .{ }^{31}$

On the second indicator, Indonesia performs unsatisfyingly. Quality assurance refers to the existing policies on international students quality, recruitment and teaching assessment for international students. It also covers quality assurance of the academic program specifically on distance learning and branch campuses. Recognition of overseas qualification including communication with labour market and foreign degree recognition. Indonesia stood at $8^{\text {th }}$ place, on the low category with Lao PDR and Myanmar which is scored very low. However, the score given is highly related to the contextual standing of Indonesia's perspective on education. Certainly, branch campuses have not yet been regulated, although the discussion has been made on whether Indonesia needs to invite this form of foreign collaboration. Regional quality assurances though exist still facing several challenges. The ASEAN University Network-Quality Assurance (AUNQA) mechanism is still deemed inclusive and elitist. Only selected Indonesia university, mostly come from public universities are part of AUN member universities. The spirit to allow for wider access nevertheless is shared widely. The ASEAN Credit Transfer System (ACTS) has not yet accepted and implemented by all university in Indonesia. The idea of somewhat a Bologna Process is vaguely shared in its implementation of a PAN ASEAN education outlook. Still, network of national and regional bodies are prevalent in which Indonesia's national body BAN-PT is a full member of regional accreditation board.

On the last indicator, Indonesia ranks the $3^{\text {rd }}$, on a very high score with Thailand, Singapore, and Malaysia. These indicators have fulfilled Indonesia especially in mobility funding both for inbound and outbound activities. Scheme for outbound mobility of LPDP scholarship by the Indonesian Ministry of Finance and Indonesian Ministry of Research and Higher Education DIKTI-BUDI scheme has supported Indonesian to go abroad. While for inbound mobility scheme such us KNB from DIKTI or Dharmasiswa from Indonesian Ministry of Education and Culture provided funds for foreigners to come to Indonesia. Research funding for research collaborations is supported through a research grant from DIKTI. Lastly Indonesia through its highlight KNB scholarship provides aid to a less developed country and Dharmasiswa program on language and intercultural competence policies. Nusantara program or World Class University program was introduced to encourage cross boundaries collaboration.

31 Kementrian Pendidikan Malaysia, Perangkaan Pendidikan Malaysia 2015, December 2015,

https://www.moe.gov.my/images/Terbitan/Buku-informasi/PerangkaanPendidikan-Malaysia-2015/Perangkaan\%20Pendidikan\%20Malaysia\%202015.pdf 
Indonesia received high in the first category, low in the second and very high on the third. It can be concluded that nationally Indonesia has the policies and environment to support students mobility. It is important to note as well that students mobility is highly dependent on the social and political context of the state. Political stability and openness are Indonesia's main attractiveness when it comes to drawing international students.

\section{Conclusion}

Special Friends of Indonesia (Indonesianists) refers to foreign students who have been spending their time in Indonesia who have experienced Indonesia through their live-in experience and have been exposed to and even internalized the values and norms of Indonesia's society. From a legal perspective, Indonesian law and regulations do not cover the legal definition to categorize Indonesianist in the legal meaning of Indonesian Diaspora. The existing Indonesian law only classifies the following categories for Indonesian Diaspora, namely Citizen Indonesia abroad, Indonesian who have relinquished their citizenship, and Foreign descendants of Indonesian. Scholars argue that Special Friends of Indonesia (Indonesianists) as a newly proposed categorization is too broad and pose a challenge for the conceptual and legal definition. Despite the conceptual conundrum of establishing a conceptual framework for Indonesianist, we can not undermine nevertheless in its implication the contribution that can be captivated by Indonesia is paramount.

It can be concluded that the nurturing of future Indonesianist is best to take place in the situation allowing for exposure and socialization process to be built internally. Education playground can be used as an incubator for the socialization process as education provides a neutral background as honest observation is collected. Besides, mobility student commonly comprised as young adults and they create their understanding of the world through experimental learning that would have an impact to construct a more understanding of multiculturalism. In addition, student mobility provides a lengthy duration for students to immerse in the new environment. Undeniably, student mobility platform provides fertile ground to nurture the future Indonesianist. It seems quite realistic to pursue this idea as the current position of Indonesia within ASEAN on its education's provision is promising and just simply needs to increase its education competitiveness. 


\section{BIBLIOGRAPHY}

\section{Book}

Brah, Avtar. Cartographies of diaspora: Contesting identities. New York: routledge, 2005.

Clifford, James. Routes: Travel and translation in the late twentieth century. Cambridge MA: Harvard University Press, 1997.

Cohen, Robert. Global Diaspora: An Introduction. London: UCL Press, 1997

Cull, Nicholas J. "Public diplomacy: Lessons from the past." $C P D$ Perspectives on Public. Los Angeles: Figueora Press, 2009

Ember, M., Ember, C. R., \& Skoggard, I. (Eds.). (2004). Encyclopedia of Diasporas: Immigrant and Refugee Cultures Around the World. Volume I: Overviews and Topics; Volume II: Diaspora Communities. Springer Science \& Business Media.

Ilieva, J., P. Killingley, V. Tsiligiris, and M. Peak. "The shape of global higher education: international mobility of students, research and education provision. Volume 2. London: British Council, 2017.

Ilieva, Janet, and Michael Peak. "The shape of global higher education: National policies framework for international engagement." London: British Council, 2016.

Cooper, Andrew F., Jorge Heine, Ramesh Thakur, and Ramesh Chandra Thakur, eds. The Oxford handbook of modern diplomacy. Oxford University Press, 2013.

d'Hooghe, Ingrid, and Jan Melissen. The New Public Diplomacy: Soft Power in International Relations, 2005

Nye, Joseph S. The future of power. New York: Public Affairs, 2011.

Santoso, Iman. Diaspora, globalisasi, keamanan, dan keimigrasian. Bandung: Pustaka Reka Cipta, 2014.

Sheffer, Gabriel. Diaspora politics: At home abroad. Cambridge: Cambridge University Press, 2003.

Trent, Deborah Lee. "American Diaspora Diplomacy U.S. Foreign Policy and Lebanese Americans." The Hague: Netherlands Institute of International Relations 'Clingendael'. 2012.

Verma, Sohali. Instruments of engagement: Assessing India's PIO and OCI scheme, CARIM-India RR 2013/21. Robert Schuman Centre for Advanced Studies. San Domenico di Fiesole (FI): European University Institute, 2013.

\section{Chapter in Book}

Hadiwinata, Bob Sugeng. "Reciprocity and Relationship Building through Education: the ACICIS Field Study Program in West Java." in Linking people: Connections and Encounters between Australians and Indonesians, 135-152. Berlin: Regiospectra, 2015

Purdey, Jemma. "Investing in good will: Australia's scholarship programs for Indonesian tertiary students, 1950s-2010." in Linking people: Connections and encounters between Australians and Indonesians, 111-132. Berlin: Regiospectra, 2015 
The Diaspora Project on Education Sector: Cultivating Positive Perception of Indonesia Through International Education

Ratih Indraswari and Nyoman Mas Aryani

\section{Journal Article}

Axel, Brian Keith. "National Interruption: Diaspora Theory and Multiculturalism in the UK." Cultural Dynamic 14, no. 3 (2002): 23556. https://doi.org/10.1177/09213740020140030101

Baubock, Rainer. "Stakeholder citizenship and transnational political participation: a normative evaluation of external voting." Fordham $L$. Rev. 75 no. 5 (2007): 2393-2447

Brubaker, Rogers. "The 'diaspora' diaspora." Ethnic and Racial Studies 28, no.1 (2005): 1-19. https://doi.org/10.1080/0141987042000289997

Byrne, Caitlin, and Rebecca Hall. "Australia's international education as public diplomacy: Soft power potential." Clingendael Discussion Paper in Diplomacy 121 (2011): 1-27.

Byrne, Caitlin, and Rebecca Hall. "Realising Australia's international education as public diplomacy." Australian Journal of International Affairs 67, no. 4 (2013): https://doi.org/10.1080/10357718.2013.806019

George, Glynis. "The Canadian Tamil diaspora and the politics of multiculturalism." Identities 18, no. 5 (2011): 459-480. https://doi.org/10.1080/1070289X.2011.670610

Harijanti et al. "Citizenship and the Indonesian Diaspora: Lessons from South Korean and Indian Experiences." Border Crossing 2 no. 8 (2018): 297-310.

Harijanti, Susi Dwi, Bilal Dewansyah, Ali Abdurahman, and Wicaksana Dramanda. "Citizenship and the Indonesian Diaspora: Lessons from the South Korean and Indian Experiences."Border Crossing 8, no. 2 (2018). 297-310.

Ho, Elaine LE, and Fiona McConnell. "Conceptualizing 'diaspora diplomacy': Territory and populations betwixt the domestic and foreign." Progress in Human Geography 43, no. 2 (2019): 235-255. https://doi.org/10.1177/0309132517740217

Karim, Karim H. "Nation and diaspora: Rethinking multiculturalism in a transnational context."International Journal of Media \& Cultural $\begin{array}{llll}\text { Politics 2, } & \text { no. } & 3 & \text { 267-282. }\end{array}$ https://doi.org/10.1386/macp.2.3.267_1

Kingsbury, Damien. "Knowing Indonesia: Intersections of Self, Discipline, and Nation ed. by Jemma Purdy." Indonesia 96, no. 1 (2013): 203207. https://doi.org/10.1353/ind.2013.0024

Nesbitt-Larking, Paul. "Dissolving the diaspora: Dialogical practice in the development of deep multiculturalism." Journal of Community \& Applied Social Psychology 18, no. 4 (2008): 351-362. https://doi.org/10.1002/casp.956

Nye Jr, Joseph S. "Public diplomacy and soft power." The annals of the American academy of political and social science 616, no. 1 (2008): 94-109. https://doi.org/10.1177/0002716207311699

Rana, Kishan. "India's Diaspora Diplomacy." The Hague journal of $\begin{array}{llll}\text { diplomacy 4, no. } & 3 & \text { (2009): }\end{array}$ https://doi.org/10.1163/187119109X455955 
Safran, William. "Diasporas in modern societies: Myths of homeland and return." Diaspora: A journal of transnational studies 1, no. 1 (1991): 83-99. https://doi.org/10.1353/dsp.1991.0004

Sheffer, Gabriel Gabi. "Transnationalism and ethnonational diasporism." Diaspora: A Journal of Transnational Studies 15, no. 1 (2006): 121-145. https://doi.org/10.1353/dsp.0.0029

Sitabuana, Tundjung Herning. "Indonesian Chinese Diaspora, Dual Citizenship and Indonesian Development." Constitutional Review 1, no. 1 (2015): 50-71.

Tsagarousianou, Roza. "Rethinking the Concept of Diaspora: Mobility, Connectivity and Communication in a Globalised World." Westminster Papers in Communication and Culture 1, no. 1 (2004): 52-65. https://doi.org/10.16997/wpcc.203

\section{Website Content}

Basnur, A. "Pemberdayaan Masyarakat Indonesia di Luar Negeri Untuk Kepentingan Nasional." Kementrian Luar Negeri Republik Indonesia. 2017. informasi/Documents / Paparan\% 20 https://www.kemlu.go.id/id/lembar20Forum\%20Bakohumas\%20Tematik\%20Kemlu\%202017.pdf

Byrne. C, Rebecca Hall. International Education as Public Diplomacy. Research Digest 3. https://www.ieaa.org.au/documents/item/258

Indonesia Diaspora Network. "Deklarasi Diaspora Indonesia", http://www.diasporaindonesia.org/index.php/idn/programmes

"Kehadiran Kartu Diaspora Indonesia Mendapat Tanggapan Negatif." Detiknews.com. https://news.detik.com/abc-australia/d3613331/kehadiran-kartu-diaspora-indonesia-mendapattanggapan-negatif.

Kementrian Pendidikan Malaysia. Perangkaan Pendidikan Malaysia 2015. https://www.moe.gov.my/index.php/menumedia/mediacetak/penerbitan/terbitan/buku-informasi/1581-perangkaanpendidikan-malaysia-2015-1/file

Zubaidah, Neneng. "Jumlah Mahasiswa Asing Meningkat." Koran Sindo. http://koran-sindo.com/page/news/2017-0515/0/9/Jumlah_Mahasiswa_Asing_Meningkat

\section{Legal Documents}

Government Regulation of the Republic of Indonesia No. 26 Year 2016 concerning Amendment to Government Regulation No 31 Year 2013 Concerning Implementation of Law No. 6 Year 2011 concerning Immigration

International Covenant of Civil and Political Rights

Law of the Republic of Indonesia No. 62 Year 1958 concerning Citizenship of the Republic of Indonesia

Law of the Republic of Indonesia No. 12 Year 2005 concerning the Ratification of International Covenant of Civil and Political Rights

Law of the Republic of Indonesia No. 12 Year 2006 concerning Citizenship of the Republic of Indonesia

Law of the Republic of Indonesia No. 6 Year 2011 concerning Immigration 
The Diaspora Project on Education Sector: Cultivating Positive Perception of Indonesia Through International Education

Ratih Indraswari and Nyoman Mas Aryani

Minister of Foreign Affairs of the Republic of Indonesia Regulation No. 7 of 2017 concerning the Issuance and Revocation of Indonesian Community Overseas Cards

Presidential Regulation No 76 Year 2017 concerning Facility for Oversea Indonesians Community

\section{Case Law}

Decision of the Constitutional Court of the Republic of Indoensia No. 80/PUU-XIV/2016

\section{Other Document}

Jovenir, Christelle M. "Diaspora Diplomacy: Functions, Duties, and Challenges of an Ambassador." Understanding Diaspora Diplomacy (June 2013). 